findings will identify around $80 \%$ of the patients with severe disease who have a poor prognosis and are candidates for a trial of energetic measures. ${ }^{6} 7$

Traditionally surgery has been reserved for those patients who have complications such as pseudocyst or abscess formation. To this may now be added the immediate surgical management of associated gall stone disease, particularly if there are stones in the common bile ducts; it helps to prevent early relapses of acute pancreatitis. ${ }^{6}$ Total or subtotal resection of the pancreas has been tried; it carries a mortality of around $25 \%$ and clearly must be reserved for severe cases - indeed, it has not been shown to confer any clear benefits. ${ }^{8}$ In one recent series of 40 resections carried out between 1973 and 1978,11 patients died in the postoperative period and there were four later deaths. ${ }^{9}$ When 24 of the 25 survivors were reviewed five to 11 years after surgery no fewer than 10 had developed polyneuropathy, and in five of these the complaint had been disabling. All but two of the survivors had diabetes mellitus.

Specific treatment in acute pancreatitis is likely to help only a few patients, and the numbers are likely to be too small for clinical trials to produce convincing evidence of benefit. For the present the surgeon considering pancreatic resection is well counselled to reach rather slowly for his scalpel.

M C BATESON

Consultant Physician,

Bishop Auckland General Hospital,

Bishop Auckland DL14 6AD

1 Soergel K. Acute pancreatitis. In: Sleisenger MH, Fordtran JS, eds. Gastrointestinal disease. Philadelphia: W B Saunders, 1983:1462-85.

2 Sarner M, Cotton PB. Classification of pancreatitis. Gut 1984;25:756-9.

Blamey SL, Imrie CW, O'Neill J, Gilmour WH, Carter DC. Prognostic factors in acute pancreatitis. Gut 1984;25:1340-6.

McMahon MJ. Acute pancreatitis, the role of peritoneal lavage. In: Mitchell CJ, Kelleher J, eds. Pancreatic disease in clinical practice. London: Pitman Medical, 1981:321-33.

Mayer AD, McMahon MJ, Corfield AP, et al. A randomised trial of peritoneal lavage for the treatment of severe acute pancreatitis. N Engl f Med 1985;312:399-404.

6 Imrie CW, Shearer MG. Diagnosis and management of severe acute pancreatitis. In: Russell RCG, ed. Recent advances in surgery. Edinburgh: Churchill Livingstone, 1986:143-54.

Corfield AP, Cooper MJ, Williamson RCN, et al. Prediction of severity in acute pancreatitis. A prospective comparison of three prognostic indices. Lancet 1985;ii:403-7.
partion

prospective comparison of three prognostic indices. Lancet 1985;ii:403-7.
8 Kivilaasko E, Lempinen M, Makelainen A, Nikki P, Schrodert T. Preventive resection versus Kivilaasko E, Lempinen M, Makelainen A, Nikki P, Schrodert T. P
peritoneal lavation for acute pancreatitis. Ann Surg 1984;199:426-31.

9 Nordback $1 \mathrm{H}$, Auvinen OA. Long term results after pancreas resection for acute necrotizing pancreatitis. Br $\mathcal{F}$ Surg 1985;72:687-9.

\title{
The Mental Health Act Commission
}

The publication of the first biennial report of the Mental Health Act Commission provides an opportunity to take stock.' Its predecessors date from 1774, since which time there had been one form or another of inspectorate to ensure compliance with mental health legislation until 1960, when the Board of Control was disbanded-leaving no independent body with a statutory duty to visit psychiatric hospitals and to safeguard the interests of patients. ${ }^{2}$ Probably as a result the 1960 s and 1970s saw a succession of scandals about conditions in mental hospitals-Ely, Farleigh, Whittingham, South Ockendon, Normansfield, Rampton. Allegations of neglect, ill treatment, cruelty, and inadequate medical and nursing care were repeatedly substantiated.

In 1969 the Hospital Advisory Service was set up to encourage and disseminate good practice and to advise the Secretary of State on standards of care and management practices in hospitals. The Department of Health and Social Security was, however, not keen to reinstitute a commission, and in 1978 it proposed instead to try some experimental schemes of patients' advisers. ${ }^{3}$ The re-establishment of a commission had frequently been advocated by the Royal College of Psychiatrists, and in 1981 the government changed heart after the publication of the report of the review of Rampton Hospital, which made a strong case for an appointed body to inspect and monitor all institutions housing detained patients. ${ }^{4}$

The Mental Health (Amendment) Bill required the Secretary of State to set up a special health authority to exercise a general protective function and to be "a real safeguard" for detained patients. ${ }^{5}$ When the Bill was introduced in the House of Lords the government spokesman said he believed the authority would build up a body of knowledge and experience which would "throw light on the whole field of mental health." Attempts were made in both Houses of Parliament to extend the remit of the commission to informal patients, but this was rejected by the government-partly on the grounds that they already benefited from other bodies such as the Health Service Commission, the Health Advisory Service, and the Court of Protection, and partly on the grounds that the commission might need to be 20 times as large, diluting its work in relation to detained patients. ${ }^{6}$

The commission was set up on 1 September 1983 and has cost the taxpayer about one million pounds a year. As a special health authority it is responsible to the Secretary of State, but it is an independent body with a chairman and 91 other part time members from medicine, nursing, law, social work, psychology, lay public, and academics. The commission's functions are to protect the interests of detained patients by visiting and interviewing them in hospitals, investigating complaints by and about detained patients, and keeping under review the way in which the powers and duties are specified in the Mental Health Act. It also provides second opinions by appointed doctors on consent to treatment and is required to prepare for the Secretary of State a code of practice for the guidance of doctors and the staff of hospitals in relation to the admission and treatment of patients suffering from mental disorder. A draft code of practice was, indeed, sent out for consultation to professional bodies by the Secretary of State in December 1985.

In its first two years the members of the commission have paid nearly 1000 visits to some 500 hospitals, and its report records their admiration for the unsparing dedication shown by so many members of staff whom they met. The commission says it has aimed at being "a catalyst of good practice, to observe and detect both the good and the bad policies and to disseminate the good."

The Act requires the commission to investigate any complaint made by a detained patient which he considers has not been satisfactorily dealt with by the hospital managers. This is the normal route, which the commission initially recommends, but a primary investigative function is not ruled out in some cases. The biennial report gives some details 
of the 1549 communications which might broadly be called complaints; 533 of these were judged as needing investigation, and some examples are given. The commission believes that its advent undoubtedly led to expectations by patients that it would be possible at last to cut through obstacles to a clear outcome. "The Commission was thought to be endowed with teeth. In fact it does not bite very much, but it can exert pressure, and exert it in increasing degrees in the right quarters."

The Mental Health Act 1983 requires a consultant psychiatrist to seek a concurring second opinion from a doctor appointed by the Mental Health Act Commission when he proposes to administer electroconvulsive therapy or medication beyond three months to a patient who is incapable of or refuses consent. In general, these requirements have been accepted and most practitioners have adopted the system without complaint and with increasing ease. A high measure of agreement, probably over $90 \%$, has been found between appointed doctors and consultants. Some difficulties have emerged: for example, no formal appeals mechanism exists for consultants against the refusal of an appointed doctor to provide an authorising certificate, coherently written treatment plans supporting the proposal for treatment are sometimes lacking, and the qualified professionals whom the appointed doctor is required to consult before issuing any certificate have not always been available.

The section in the report on the special hospitals will confirm the impression of many of their staff that the commission came in with many preconceived ideas and suspicions. For its part the commission believes that the staff's initial suspicion has not been easily or totally overcome. "Much is still left to do," but it records its recognition of the personal commitment and service of special hospital staff. The report shows that the commission still has a less than complete understanding of the need in special hospitals to balance treatment with security; and it produces no evidence to support its claim that some patients make complaints only when they feel that it is "safe" to do so. The DHSS will probably be annoyed by the statement that the special hospital managers do not appear to have considered how the complaints procedures which the department correctly enforces in National Health Service hospitals might be translated into the special hospitals. Complaints procedures do exist in special hospitals, and the Department of Health has been working hard for some time to bring these together into a uniform policy. The Home Office comes in for criticism over delays in the implementation of recommendations for transfer to other hospitals; such delays should be the inevitable consequence of proper consideration rather than of avoidable bureaucracy.

The commission says that one of its most vexatious tasks is to decide whether detained patients can be given compulsory treatment while on leave of absence in the community. There will be wide support for the view that consideration should be given to legislation for a community treatment order, particularly after the recent ruling by the Court of Appeal that certain means to accomplish this end are unlawful. ${ }^{8}$

The programme for action for the future gives 26 problems which the commission believes remain unresolved. It is still debating whether it should request the Secretary of State to direct that it should keep under review the care and treatment of informal patients who are physically detained against their expressed wishes in a locked ward or room. It is also increasingly concerned about the position on consent to treatment of long stay informal patients and of the mentally disordered in prison for whom no hospital place could be found or who have become mentally disordered while serving $\underline{\underline{T}}$ sentence.

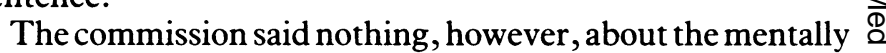
disordered in the community for whom no hospital places are made available. "Ease a tragedy, stop a scandal" was the heading for a recent editorial in The Times on the plight of schizophrenics in the community. ${ }^{9}$ The Social Services $\mathbb{D}$ Committee of the House of Commons has castigated the m government for trying to remove hospital facilities for the mentally ill before adequate alternatives have been established, ${ }^{10}$ adding that "great difficulties are being experienced in procuring emergency psychiatric care, putting a strain on the individuals concerned and their families. That is the present reality of community care as seen by many families."

Last year a young man suffering from acute schizophrenia was taken by his uncle to his general practitioner for help. Despite his saying that his nephew was suicidal and behaving dangerously the doctor would not see him. The uncle took him to the nearest psychiatric outpatient department, where he was told he could not be seen without a letter from his family doctor. Eventually a social worker was sent for, arrived at the uncle's house, and was decapitated by the ? psychotic young man, who believed her to be the devil who had come to take him to hell. In November the patient was found not guilty by reason of insanity and admitted to Broadmoor. ${ }^{11}$

Where, indeed, are the scandals the Mental Health Act Commission was set up to counteract? Its biennial report shows no evidence that they are to be found in mental hospitals. The evidence of the Social Services Committee and $\stackrel{\rho}{\Im}$ the series of articles on schizophrenia in The Times last December ${ }^{12-14}$ show that today the scandals lie in the failure of $\%$ psychiatric services to provide care. The scandal of the decapitated social worker is in some ways worse than the abuses found in the mental hospital inquiries in the past two decades.

Certainly consideration should be given to changing the remit of the commission, but not necessarily only in the way suggested in the biennial report. Perhaps some of the hospital visiting and "domestic" complaints might be taken over by the Health Advisory Service and community health councils; they should get together with the commission and the DHSS to work out their respective contributions. The commission will do a better service to psychiatric patients and their relatives if it is given the power to investigate why patients are not in hospital as well as the problems they encounter when they are admitted.

JOHN R HAMILTON 운

Medical Director,

Broadmoor Hospital,

Crowthorne RH11 7EG

\footnotetext{
1 Mental Health Act Commission. The first biennial report of the Mental Health Act Commission 198385. London: HMSO, 1985.

2 Hamilton JR. Mental Health Act 1983. BrMed $\mathcal{f}$ 1983;286:1720-5.
3 Department of Health and Social Security, Home Office, Welsh Office, Lord Chancellor's Department. Review of the Mental Health Act 1959. London: HMSO, 1978.

4 Department of Health and Social Security. Report of the review of Rampton Hospital. London: HMSO, 1980

5 Department of Health and Social Security, Home Office, Welsh Office, Lord Chancellor's Department. Reform of mental health legislation. London: HMSO, 1981.

6 Lord Elton. Committee stage of the Mental Health (Amendment) Bill. House of Lords Official Report (Hansard) 1982 Feb 1;426:cols 1137-52. (No 32.)

7 Clarke K. Special standing committee on Mental Health (Amendment) Bill. House of Common Official Report (Hansard) 1982 June 17:cols 572-6.

8 Anonymous. Detention lawful for in-patient treatment only. The Times $1985 \mathrm{Dec} 28: 8$ (cols 1-6)

9 Anonymous. Ease a tragedy, stop a scandal [Editorial]. The Times 1985 Dec 19:13 (cols 1-3)

10 House of Commons Social Services Committee. Community care with special reference to adult mentally ill and mentally handicapped persons. London: HMSO, 1985.

1 Anonymous. Horror death of "mercy angel." Homsey foumal 1985 Dec 6:5 (cols 1-6).

11 Anonymous. Horror death of "mercy angel." Homsey foumal 1985 Dec 6:5 (cols $1-6)$.

12 Wallace $M$. When freedom is a life sentence. The Times $1985 \mathrm{Dec} 16: 10$ (cols 1-8).
$13 \mathrm{~W}$ allace $M$. Through an open door to despair. The Times $1985 \mathrm{Dec} 17: 8$ (cols 1-8).
}

14 Wallace M. A patient's cry-can nobody help? The Times $1985 \mathrm{Dec} 18: 8$ (cols 1-7). 